\title{
Nexilin mutations are associated with left ventricular noncompaction cardiomyopathy
}

E Pardun,,$\stackrel{\text { Aff1 Aff2 }}{\text { Corresponding Affiltati }}$

Corresponding Affiliation: Aff1

K Wenzel, $\stackrel{\text { Affl }}{ }$

H-H Kramer, $\frac{\text { Aff2 }}{}$

F Berger, $\frac{\text { Aff1 }}{\text {, }}$

B Gerull, $\stackrel{\text { Aff3 }}{,}$

S Klaassen, $\frac{\text { Aff1 }}{\text { }}$

\begin{tabular}{|c|c|c|}
\hline \multicolumn{3}{|r|}{ ArticleInfo } \\
\hline ArticleID & $:$ & 47 \\
\hline ArticleDOI & $:$ & 10.1186/2194-7791-2-S1-A7 \\
\hline ArticleCitationID & $:$ & A7 \\
\hline ArticleSequenceNumber & $:$ & 7 \\
\hline ArticleCategory & $:$ & Meeting abstract \\
\hline ArticleFirstPage & $:$ & 1 \\
\hline ArticleLastPage & $:$ & 2 \\
\hline ArticleHistory & $:$ & $\begin{array}{ll}\text { RegistrationDate } & : 2015-7-1 \\
\text { OnlineDate } & : 2015-7-1\end{array}$ \\
\hline ArticleCopyright & $:$ & $\begin{array}{l}\text { Pardun et al.2015 } \\
\text { This article is published under license to BioMed Central } \\
\text { Ltd. This is an Open Access article distributed under the } \\
\text { terms of the Creative Commons Attribution License } \\
\text { (http://creativecommons.org/licenses/by/4.0), which permits } \\
\text { unrestricted use, distribution, and reproduction in any } \\
\text { medium, provided the original work is properly cited. }\end{array}$ \\
\hline
\end{tabular}

Aff1

Dept. of Pediatric Cardiology, ECRC, University Medicine-Charité, Berlin, Germany

Aff2

Dept. of Congenital Heart Disease, University Clinic, Kiel, Germany

Aff3

University of Calgary, Calgary, Alberta, Canada 
Abstracts of the 51st Workshop for Pediatric Research

51st Workshop for Pediatric Research

Göttingen, Germany

16-17 April 2015

This supplement has not been sponsored.

Meeting abstracts

\section{Introduction}

Left Ventricular Noncompaction Cardiomyopathy (LVNC) is a very rare congenital heart disease. LVNC is a form of cardiomyopathy in which the fetal myocardium fails to "compact" during cardiac development and it may be associated with impairment of LV function and LV dilatation. Mutations in several sarcomere genes have been described in LVNC. Nexilin, encoded by NEXN, is a cardiac Z-disc protein that stabilizes the sarcomere. We evaluated nexilin as a disease gene for LVNC.

\section{Methods}

Ninety-two LVNC patients and 254 controls were screened and NEXN was sequenced by Sanger sequencing.

\section{Results}

We found a missense mutation (c.1408 G>C, p.Glu470Gln) in one patient and a nonsense mutation in another patient (c.1723G>T, p.Glu575*). None of these mutations were detected in the healthy controls. In addition, we identified one single nucleotide polymorphismus (c.733G $>$ A, p.Gly245Arg) homozygous in two and heterozygous in three LVNC patients. This polymorphism was also found in 78 controls (homozygous in 12 and heterozygous in 64 controls).

\section{Conclusion}

Mutations in genes encoding Z-disc proteins such as nexilin have been shown to cause different forms of cardiomyopathy. Therefore, the two mutations we identified in NEXN may further increase our knowledge of Z-disc genes in the pathogenesis of LVNC. To establish the disease causality, it is necessary to investigate the effect of the mutations on protein function in further in vitro studies. 